\title{
The Level of Welfare of LPD Members Desa Adat Abiantuwung Kecamatan Kediri Reviewed from the Social Enterprise Approach
}

\author{
Diota Prameswari Vijaya ${ }^{1, *}$ Gusti Ayu Ketut Rencana Sari Dewi ${ }^{1}$ Ni Wayan \\ Yulianita Dewi ${ }^{1}$ \\ ${ }^{I}$ Department of Economic and Accounting Department, Universitas Pendidikan Ganesha, Singaraja, Indonesia \\ ${ }^{*}$ Corresponding author. Email: diota.pv@undiksha.ac.id
}

\begin{abstract}
The study aims at determining the level of welfare of the members of the Abiantuwung Village Credit Institution (Lembaga Perkreditan Desa/LPD) in terms of the dimensions of social value, civil society, innovation, and economic activity. This study is descriptive research. The population in this study were 493 members of the Abiantuwung Traditional Village LPD and a sample of 220 people using random sampling techniques. Data were collected using a questionnaire and documentation. Data were analyzed using descriptive analysis techniques. The results showed that the welfare level of the Abiantuwung Traditional Village LPD members in terms of the social value dimension in total was in the agree category with a score of 3235 , the welfare level of the Abiantuwung Traditional Village LPD members in terms of the civil society dimension in total was in the agree category with a score of 2804, the level of welfare members of the Abiantuwung Traditional Village LPD in terms of the innovation dimension are totally in the agree category with a score of 2803, the welfare level of the Abiantuwung Traditional Village LPD members in terms of the economic activity dimension the total is in the agree category with a score of 1664 .
\end{abstract}

Keywords: Social Value, Civil Society, Innovation, Economic Activity.

\section{INTRODUCTION}

[1] mandates the government to implement regional autonomy by adhering to the principle of decentralization. Autonomy confers complete control on the regions, allowing them to run an autonomous and innovative administration that is committed to promoting regional welfare. The concept of regional autonomy is related to respect for regional peculiarities, so the government grants autonomy rights to villages. The purpose of regional autonomy is to optimize the development of community welfare, including rural communities so that the central point of development is rural areas.

One method to strengthen the village economy is to promote village entrepreneurship as a strategy for development and expansion of welfare [2]. Entrepreneurship is a creative and imaginative aptitude, continuously looking for new prospects and changes [3]. Entrepreneurship is intended to help companies grow and prosper, and entrepreneurship that benefits society can be achieved by adopting the notion of social entrepreneurship [3].
Socio-economic issues such as poverty, environmental degradation, and welfare are addressed through social entrepreneurship [4]. Social entrepreneurs see challenges as opportunities to innovate and empower society. [5] state that social entrepreneurship is the utilization of entrepreneurial behavior that is more geared towards achieving social goals than making profits, or revenues are used for social interests. [6] defines social entrepreneurship as combining a social objective with commercial discipline, innovation, and determination. Social entrepreneurship can be a) non-profit, b) for-profit with a social purpose, or c) a blend of the two.

Social entrepreneurship combines commercial, charity, and social movement paradigms to create sustainable social solutions. [7] divides the notion of social entrepreneurship into three parts: (1) Social entrepreneurship is the idea of a non-profit organization seeking funding for its activities when the government, individuals, or companies temporarily stop funding it. Social demands are rising. This first version emphasizes the need for creative solutions to problems related to social funding, (2) Social entrepreneurship focuses on individuals who have solutions to social issues. The individual part focuses on the social entrepreneur's 
actions, showing the traits or character of a social entrepreneur. It has a leadership element; (3) Social entrepreneurship is considered as a business entity's social responsibility practice through a cooperative method. This third category is now known as Corporate Social Entrepreneurship (CSE). Social entrepreneurship has four dimensions: value, society, innovation, and economics [8].

Social entrepreneurship mixes business, charity, and social movement models to produce sustainable solutions to social challenges and social value orders. [7] divides the notion of social entrepreneurship into three parts: (1) Social entrepreneurship is the idea of a non-profit organization seeking funding for its activities when the government, people, or companies temporarily cease financial support. Social requirements are increasing. This first type illustrates the need for creative solutions to difficulties related to finding funding for socially beneficial activities. (2) Social entrepreneurship focuses on individuals who have solutions to social issues. The individual part focuses on the social entrepreneur's actions, showing the traits or character of a social entrepreneur. (3) Social entrepreneurship is considered as a business entity's social responsibility practice through a cooperative method. This third category is now known as Corporate Social Entrepreneurship (CSE) (CSE). Social entrepreneurship has four elements, according to [8]: social value, civil society, innovation, and economic activity.

\subsection{Social Value}

As the most distinguishing characteristic of social entrepreneurship, it is the ability to generate tangible social benefits for the benefit of the community and the surrounding environment. Social value in this case is a terminology which is rather difficult to define. One statement from [9] regarding the definition of Social entrepreneurship is an effective and inventive activity that strategically focuses on overcoming social market failures and developing new chances to create social value.. Dewey (1939, in [10]) states that in general, social value creation is things that can increase welfare in general. According to [6] the best way to measure the success of social entrepreneurship is not by calculating the amount of profit generated, but at the level at which they have generated social values. The term social value is used to distinguish it from the term economic value creation, which tends to limit itself to a measure of financial income so that social entrepreneurship activists must always struggle with finding new or different opportunities in creating or maintaining value-social value (social value).

Efforts to discover and create new opportunities can be done in order to create and maintain social values. For the purposes of research on social entrepreneurship, of course this is something that is important to discuss, because the creation of opportunities will determine the life and death of social entrepreneurship activities. One of the factors that can support opportunity finding efforts is strategic planning. Therefore, a strategic plan can be a unifying document, a compass or a roadmap for the organization. [6] states that opportunities can give an organization direction, and help create or maintain social value. Furthermore, the ability to recognize and attract opportunities is an indispensable skill for success in the world of non-profit organizations. From the explanations of several experts above, it can be concluded that the indicators of social value are providing social value or benefits, overcoming market failures and creating new opportunities in society.

\subsection{Civil Society}

Social entrepreneurship generally comes from the initiative and participation of civil society by optimizing existing social capital in society. Meanwhile, along with the development of the entrepreneurial movement itself, the social dimension of social entrepreneurship is starting to get a sharper spotlight, that is, social entrepreneurship is ideally formulated by local community members who feel certain inconveniences, or because they see a certain potential that can be developed. According to the EMES research group (Spear \& Binet 2003 in [9]) the definition/meaning of social elements in social entrepreneurship is as follows.

a. An activity launched by a group of citizens (an activity carried out by a group of citizens).

b. Decision making power is not based on capital ownership.

c. Limited profit distribution.

Based on the explanation above, the social element in social entrepreneurship refers to an activity carried out by citizens, the level of decision making that is not based on capital ownership, as well as clear goals and targets to be of benefit to society.

\subsection{Innovation}

The purpose of an innovation is a change or improvement from present conditions to be better, however not all changes can be said to be an invention [11]. Innovation is closely related to entrepreneurship. Opportunities, better systems, new ideas, and solutions to better environmental changes are the cornerstone of social innovation for a social entrepreneur [12]. A social entrepreneur works for creative ways to get his business the resources it needs to create social benefit [13].

Social entrepreneurship solves social issues creatively by integrating local knowledge and social innovation. In the context of social entrepreneurship, the intended value is social because the focus is on creating innovative solutions to social issues. "Innovation is the ability to apply innovative solutions to problems and opportunities," says Zimmerer in [14]. A fresh concept is employed to launch or improve a product, method, or 
service, according to Stephen Robbins [14]. According to [15], innovation may add value to the firm, shareholders, and the community. In short, most definitions of innovation include creating and implementing something new. [15] defines four dimensions of inventive conduct in the innovation process.

\subsubsection{Observing Opportunities}

Opportunities can originate from discrepancies that occur because of the incompatibility of the expected pattern, for example the emergence of problems in the community that has already taken place, the community's needs that have not been fulfilled, or an indication of trends that are changing.

\subsubsection{Develop Ideas}

In this phase, entrepreneurs can issue new concepts with the aim of improvement and renewal. This includes coming up with new ideas or updating services, client meetings and technology support. The key to generating ideas is to combine and reorganize pre-existing information and concepts to solve problems and/or improve performance.

\subsubsection{Fight for}

The point here is to develop and implement ideas, an entrepreneur must have behavior that refers to results. Convergent innovation behavior includes trying to be a champion and working hard. A person who behaves champion puts all his effort into creative ideas. Champion efforts include persuading and influencing employees and negotiating. Implementing innovations often requires coalitions, gaining strength by selling ideas to potential partners.

\subsubsection{Applications}

Entrepreneurship comprises developing, testing, and promoting new services. This relates to creating new work procedures or improving existing ones.

\subsection{Economic Activity}

Generally, successful social entrepreneurship involves combining social and business interests. Economic operations are established to ensure the social mission's independence and sustainability. One thing that distinguishes social enterprise and business enterprise is that decision making is not based on share ownership. This is the character of a social enterprise where the main purpose of its activities is to maximize social benefits. If likened to a continuum, the social enterprise is on the opposite side of the business enterprise. Some experts say that a social enterprise has a social dimension while a business enterprise has an economic dimension. Social entrepreneurship operates in distinctive ways and is different from other conventional patterns. According to John Peppin (2009, in [4]) there are several ways how social entrepreneurship activities move in society, namely as follows.

a. Business activities with social goals as the main thing, where the profit surplus is invested in the main purpose which has been determined previously.

b. Activities carried out by the voluntary sector, in which an honorarium is paid in return for the completion of a product or service. This means that social entrepreneurial activities can move in the business area with clear social goals, or in the voluntary sector with a clear profit distribution. Institutions that become the umbrella of the social entrepreneurship movement are often known as social enterprises.

Based on what has been described above, basically social entrepreneurship is an integration of entrepreneurial ideals that prioritize economic operations but also social benefit. Using an entrepreneurial approach, social entrepreneurship can help reduce poverty. This means that the basic concepts of entrepreneurship, such as innovation, opportunityoriented, visionary, and so on, are implemented within the framework of social activities.

The Village Credit Institution (LPD) is one of the village financial institutions owned by the Bali Provincial Government. LPD was established in order to improve the welfare of rural communities by creating and providing services in the financial sector. In other words, the Village Credit Institution (LPD) in Bali is basically to help development in each customary village or pekraman village as a force to maintain Balinese customs and culture which is a new strategic way to increase funding sources for community members.

LPD was founded in 1984 with Regional Regulation (Perda) Number 2 of 1988 concerning Village Credit Institutions as a juridical basis. The legal basis for the LPD in Bali Province was stipulated by the Decree of the Governor of Bali Number 972 of 1984 dated November 1, 1984 which was subsequently stipulated as the Regional Regulation (Perda) of the Province of Bali No. 8 of 2002 concerning Village Credit Institutions dated September 12, 2002, and promulgated on September 16, 2002 in state sheets.

With the establishment of a Credit Institution, it is very important to develop resources related to culture, social and economy. Thus the LPD has become a business engaged in the financial sector and has become an asset for the Traditional Village or Pakraman Village. As described above, the LPD is a community financial institution. As a community institution, the LPD has a community mission which will then be carried out in daily activities. The community mission held by the LPD includes a) supporting the implementation of 
culture and preserving cultural heritage in each Pakraman village; b) Encouraging the economic development of the Pakraman village community through targeted savings and effective distribution of capital; c) eradicating bonded bonds, illegal pawns and other forms of financial economic pressure that can weaken the financial and financial capacity of rural communities; d) creating equity and business opportunities for villagers and rural workers; e) increase the purchasing power of the community and smoothen traffic of payments and circulation of money in the Pakraman village environment. Of course, carrying out this mission is carried out in several forms. For the purpose of carrying out this mission, the LPD operates a business in the form of:

a. Receiving/collecting funds from the village krama (villagers) in the form of savings and deposits;

b. Offering loans exclusively to village krama;

c. Receiving loans from financial institutions up to $100 \%$ of total capital, including reserves and retained earnings, subject to other restrictions on the amount of loans or support/assistance funds;

d. Depositing excess liquidity at the Bali Regional Development Bank in exchange for competitive interest and adequate service. The placement of the excess funds in the "Bank Pembangunan Daerah (BPD)" is in favor of the BPD's position as the LPD Trustee Bank. The establishment of the LPD aims to support the role of traditional villages in supporting social, cultural, customary and religious life so that traditional villages have independent and sustainable sources of financing to finance activities related to customary affairs or other community affairs, such as: Maintenance of cultural instruments, maintenance cultural heritage, building and repairing temples, ceremonial costs and so on.

LPD was formed for the purpose of carrying out a cultural mission, only carrying out community internal economic activities (domestic, in Pakraman village households), and oriented towards improving the welfare of the Pakraman village community which basically also aims to increase the community's ability to bear the burden of maintaining civilization. The establishment of the Village Credit Institution (LPD) in the Province of Bali, which is based on the Traditional Village is associated with the preservation of the development of the Traditional Village with the following considerations.

a. The Traditional Village is a traditional institution that has roots in rural communities that are highly respected and always obeyed by the residents (krama) of the Traditional Village.

b. The Traditional Village has written and non-written rules which are respected and obeyed by the Krama of the Traditional Village. c. Kinship ties and the spirit of mutual cooperation between fellow Krama in the Traditional Village are very closely intertwined.

d. Traditional Villages have considerable obligations and responsibilities when compared to the rights they have, especially in terms of supporting and making the implementation of development in the Bali region a success.

The important role of the LPD is greatly felt by the people in Bali, especially to support activities such as odalan, Hindu holidays, and can help people who are less fortunate in education and provide sudden loan assistance if residents are considered to have problems in the business capital sector and can help the community who have sudden financial needs such as illness and funerals.

Meanwhile, in terms of services provided by LPDs to the community, namely according to customer needs, such as simple procedures, short processes, personal approaches and proximity to customers are factors for the success of the LPD. The role of the Village Credit Institution (LPD) in providing services and fostering trust in the village community, so that the community has a sense of security in saving and borrowing money from the Village Credit Institution (LPD).

The Village Credit Institution (LPD) Abiantuwung Traditional Village is one of the LPDs in Kediri District. The LPD of the Abiantuwung traditional village carries out economic activities for savings and loans. In carrying out its activities, the LPD at Abiantuwung Traditional Village does not prioritize solely on profit, but on social benefits provided to members of the Abiantuwung Traditional Village LPD. Thus, what has been done by the Abiantuwung Traditional Village LPD is in accordance with the elements of social entrepreneurship, which aim to improve the welfare of LPD members. Therefore, it is important to study how the level of welfare of the members of the LPD in the Abiantuwung Village of Kediri District in terms of the social entrepreneurship approach. In detail, this study would like to reveal 1) the level of welfare of the members of the Abiantuwung Traditional Village LPD in terms of the social value dimension? 2) the level of welfare of the members of the Abiantuwung Traditional Village LPD in terms of the civil society dimension? 3) the level of welfare of the members of the Abiantuwung Traditional Village LPD in terms of innovation dimension? and 4) the level of welfare of the members of the Abiantuwung Traditional Village LPD in terms of economic activity dimension?

\section{METHOD}

This study aims to determine the level of welfare of members of the Abiantuwung Traditional Village (LPD) in terms of social entrepreneurship of the dimensions of social value, civil society, innovation, and economic activity. The population of members of the 
Abiantuwung Traditional Village LPD, amounting to 1612 heads of families. Based on the population by using the Slovin formula, the sample is determined to be a minimum of 220 family heads.

The data collection method used in this study was a questionnaire. The questionnaire was used to explore the level of welfare of the members of the Abiantuwung Traditional Village LPD in terms of the social entrepreneurship dimension. The data that has been collected will be analyzed descriptively.

\section{RESULTS \& DISCUSSION}

\subsection{Result}

3.1.1 Welfare Level of Members of the Abiantuwung Traditional Village Credit Institution (LPD) in terms of Social Value Dimensions

In total, the welfare level of the members of the Abiantuwung Traditional Village LPD in terms of the social value dimension is in the agree category, with a score of 4,566 and is in the range of 3,593,337-4,620. This means that the community agrees with the existence of the Abiantuwung Traditional Village LPD, because the Abiantuwung Traditional Village LPD can help overcome community financial problems through savings and loan activities so that people can invest their funds, open new businesses, open job opportunities and overcome market failures. In more detail can be seen in Table 1 below.

\subsubsection{The Welfare Level of the Abiantuwung Traditional Village LPD Members in View from the Civil Society}

In total, the welfare level of members of the Abiantuwung Traditional Village LPD in terms of the civil society dimension is in the agree category, with a score of 3,262 and is in the range of 2,566,666 - 3,300. This means that the community participates in the efforts of the Abiantuwung Traditional Village LPD, although the benefits provided by the Abiantuwung Traditional Village LPD are not always in material form, and the community also feels well served by the Abiantuwung Traditional Village LPD. In more detail can be seen in Table 2 below.

Table 1. Welfare Level of Abiantuwung Tradisional Village LPD members viewed from the social value

\begin{tabular}{|c|c|c|c|c|}
\hline Dimension & Indicator & Score & Score Range & Catagory \\
\hline \multirow{3}{*}{ Social Value } & $\begin{array}{l}\text { 1. Provide social value or } \\
\text { benefits }\end{array}$ & 1.307 & $1.026,667-1.320$ & Agree \\
\hline & 2. Overcoming Market Failures & 1303 & $1.026,67-1320$ & Agree \\
\hline & 3. $\quad$ Creating new opportunities & 1956 & $1.540-1980$ & Agree \\
\hline & Total & 4566 & $3.593,337-4.620$ & Agree \\
\hline
\end{tabular}

Table 2. Welfare Level of Abiantuwung Tradisional Village LPD members viewed from the civil society

\begin{tabular}{|c|c|c|c|c|}
\hline Dimension & Indicator & Score & Score Range & Catagory \\
\hline \multirow{3}{*}{ Civil Society } & $\begin{array}{l}\text { 2. Activities carried out by a group } \\
\text { of residents }\end{array}$ & 1.953 & $1,540-1,980$ & Agree \\
\hline & $\begin{array}{l}\text { 3. Decision making is not based } \\
\text { on capital ownership }\end{array}$ & 649 & $513.333-660$ & Agree \\
\hline & \begin{tabular}{|l} 
4. \\
Financial distribution limited \\
creating new opportunities
\end{tabular} & 660 & $513.333-660$ & Agree \\
\hline \multicolumn{2}{|r|}{ 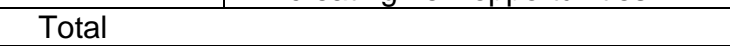 } & 3262 & $2.566,666-3.300$ & Agree \\
\hline
\end{tabular}

\subsubsection{The Welfare Level of the Abiantuwung} Traditional Village LPD Members in View from the Innovation Dimension

In total, the welfare level of the members of the Abiantuwung Traditional Village LPD in terms of the innovation dimension is in the agree category, with a score of 3,247 and is in the range of 2,496.666 -3,300. This means that the community agrees with the existence of the Abiantuwung Traditional Village LPD which has a high commitment to the welfare of the community by always trying to improve the quality of service for the community. In more detail can be seen in Table 3 below.

\subsubsection{The Welfare Level of the Abiantuwung Traditional Village LPD Members in View of the Economic Activity Dimension}

In total, the welfare level of the Abiantuwung Traditional Village LPD members in terms of the economic activity dimension is in the agree category, with a score of 2,571 and is in the range of 1,026,6671,320 . This means that the community agrees with the existence of the Abiantuwung Traditional Village LPD, 
because the Abiantuwung Traditional Village LPD is able to balance between business activities and social

Table 3. The Welfare Level of Abiantuwung Traditional Village LPD members viewed from the innovation dimension

\begin{tabular}{|c|c|c|c|c|}
\hline $\begin{array}{c}\text { Dimensio } \\
\mathbf{n}\end{array}$ & Indicator & $\begin{array}{c}\text { Scor } \\
\mathrm{e}\end{array}$ & $\begin{array}{l}\text { Score } \\
\text { Range }\end{array}$ & $\begin{array}{c}\text { Catago } \\
\text { ry }\end{array}$ \\
\hline \multirow{4}{*}{$\begin{array}{l}\text { Innovation } \\
\text { Dimension }\end{array}$} & $\begin{array}{l}\text { 1. Seeing an } \\
\text { opportunity }\end{array}$ & 652 & $\begin{array}{c}513.333- \\
660\end{array}$ & Agree \\
\hline & $\begin{array}{l}\text { 2. Bring out } \\
\text { the ide }\end{array}$ & 647 & $\begin{array}{c}513.333- \\
660\end{array}$ & Agree \\
\hline & 3. Fight for & 652 & $\begin{array}{c}513.333- \\
660\end{array}$ & Agree \\
\hline & 4. Application & $\begin{array}{l}1.29 \\
6\end{array}$ & $\begin{array}{c}1.026,667 \\
-3.300\end{array}$ & Agree \\
\hline \multicolumn{2}{|r|}{ Total } & $\begin{array}{c}3.24 \\
7\end{array}$ & $\begin{array}{l}2.496,666 \\
-3.300\end{array}$ & Agree \\
\hline
\end{tabular}

\subsection{Discussion}

\subsubsection{The Welfare Level of the Abiantuwung Traditional Village LPD Members in View from the Social Value Dimension}

Based on the research results, it can be seen that from a social value perspective, The Abiantuwung Traditional Village LPD helps the community deal with social issues, including financial issues. Savings and loans are used to solve these financial issues. Those with more money will save it in the Abiantuwung Traditional Village LPD. Those in need of finances might borrow the Abiantuwung Traditional Village LPD. The monies loaned by the community will be utilized to start new firms, thereby balancing the market and creating new opportunities. The possibility for the community to find a job and start a business with borrowed finances has been done. So, it can be said that the Abiantuwung Indigenous Village LPD provides social benefits for the Abiantuwung Indigenous village community. This is in line with the opinion of [9] that social entrepreneurship is focused on efforts to overcome market failures and the creation of new opportunities to systematically increase social value to bring about change. This is also in line with the opinion of Dewey $(1939$, in [10]) that in general the creation of social value is things that in general can increase welfare. So with the social value provided by the Abiantuwung Traditional Village LPD, it is hoped that it can improve community welfare and overcome other social problems.

\subsubsection{Welfare Level of LPD Members of} Abiantuwung Kelod Traditional Village in View from Civil Society Dimension

Based on the results of the study, from a civil society perspective, the Abiantuwung Indigenous village community contributes to the village economy, even though the rewards are not necessarily material. By activities provided for its members. In more detail, it can be seen in Table 4 below.

developing new companies and participating in the Abiantuwung Traditional Village LPD decision making, as well as maintaining the inclusion of the community to help all communities.

Like [8] believes, social entrepreneurship arises from the initiative and participation of civil society by optimizing existing social capital. The EMES research group (Spear \& Binet 2003 in [9]) believes that decision-making authority is not just based on capital ownership. A specific aim to reach by the LPD in realizing community welfare is an important issue.

\subsubsection{Welfare Level of Abiantuwung Traditional Village LPD Members in View from the Innovation Dimension.}

Based on the results of the study, it can be seen that judging from the innovation dimension, members of the Abiantuwung Traditional Village LPD agree that the Abiantuwung Traditional Village LPD is able to see opportunities and create new or innovative things that have never been implemented before. One form of innovative business is the role of the LPD in carrying out business activities to find opportunities, improve systems, find new approaches and create prosperity and solutions to better environmental changes.

This is in line with research conducted by [16] that social value creation and innovation are the main instruments in social entrepreneurship. This is also in line with the opinion of Zimmerer in [14] which states that innovation is the ability to apply creative solutions to problems and opportunities to improve or to enrich people's lives. Thus it can be said that the Abiantuwung Traditional Village LPD always tries to find innovative ways to ensure that its business will have access to the resources needed and can also create social value in order to realize the welfare of its members.

\subsubsection{The Welfare Level of the Abiantuwung Traditional Village LPD Members in View from the Economic Activity Dimension}

Based on the study's findings, members of the Abiantuwung Traditional Village LPD agree that the Abiantuwung Traditional Village LPD does not solely focus on monetary gains. The Abiantuwung Traditional Village LPD does seek to make a profit. But, to support company sustainability, achieving the welfare of LPD members is the fundamental goal. This aligns with the purpose of social entrepreneurship to enhance people's lives. To address community needs and open access to all rural communities from many aspects, successful social entrepreneurship often balances business activity and social purposes.

This is in line with research conducted by [17] [18] that the ideal BUMDes is able to become the axis of 
village community life, because it exists or exists to meet community needs, is able to absorb the production capacity of the community, and its services are open. for all rural communities from various elements. This is also in line with the opinion of John Peppin (2009, in [4]) that social entrepreneurship activities can operate in the business area with clear social goals, or in the voluntary sector with a clear profit distribution. So, between social activities, there must be a balance between business activities and social goals so that the results obtained also do not harm or benefit only one interested party.

\section{CONCLUSION}

The conclusion of this study is based on the social value dimension, the community agrees that LPD is able to help provide capital to open new businesses and open up job opportunities so as to create prosperity and reduce social problems in society. Based on the civil society dimension, the community agrees that LPD in managing its business and making decisions always involves the Abiantuwung Traditional Village community as members, which in the end is expected to realize the welfare of its members. This proves that in carrying out its activities, the Abiantuwung Traditional Village LPD uses the principles and objectives of social entrepreneurship. Based on the innovation dimension, the community agrees that LPD is able to see opportunities and create new things that are innovative, such as plans to provide scholarships for people whose children excel in education, so that it is expected to reduce the dropout rate. Based on the dimension of economic society, the community agrees that LPD in running its business is not only concerned with material gains but also for the common welfare (social goals). For example, providing financial assistance when carrying out traditional ceremonial activities.

\section{REFERENCES}

[1] U.-U. RI, Undang-Undang Republik Indonesia Nomor 32 Tahun 2004 Tentang Pemerintah Daerah. 2004.

[2] B. Ansari, S. . Mirdamadi, A. Zand, and M. Arfaee, "Sustainable Entrepreneurship In Rural Areas," J. Environ. Earth Sci., vol. 5, no. 1, pp. 26-31, 2013.

[3] R. Saragih, "Membangun Usaha Kreatif, Inovatif, dan Bermanfaat Melalui Penerapan Kewirausahaan Sosial,” J. Kewirausahaan, vol. 3, no. 2, 2017.

[4] H. Wibowo and S. A. Nulhaqim, Kewirausahaan Sosial. Bandung: UNPAD Press, 2015.

[5] H. Utomo, "Menumbuhkan Minat Kewirausahaan Sosial," Among Makarti, vol. 7, no. 14, 2014.
[6] G. . Dees, "The Meaning Of Social Entreprenuership," Pap. Stanford Kauffman Cent. Entrep. Leadersh., 2001.

[7] Seelos and Mair, "Social Entreprenuership-The Contribution Of Individual Entrepreneurs To Sustainable Development," IESE Bus. Sch. Work. 2004.

[8] L. Hulgard, Discourses Of Social Entreprenuership-Variations Of The Same Theme? Liege: EMES European Research Network, 2010.

[9] A. Nicholls, Social Entreprenuership: New Models Of Sustainable Social Change. New York: Oxford University Press, 2008.

[10] G. . Lumpkin et al., "Entrepreneurial Processes In Social Context: How Are They Different, If At All?," Small Busines Econ, 2011.

[11] L. Saiman, Kewirausahaan. Jakarta: Salemba Empat, 2011.

[12] R. Widiastuti and M. Marharetha, "Socio Entrepreneurship: Tinjauan Teori Dan Perannya Bagi Masyarakat," J. Manaj. Univ. Kristen Maranatha, vol. 11, no. 1, 2011.

[13] G. S. Mort and J. Weerawardena, "Social Entrepreneurship: Towards Conceptualization," Int. J. Nonprofit Volunt. Sect. Mark., vol. 8, no. 1, 2003.

[14] Putra, Potensi Penerapan Produksi Bersih Pada Usaha Peternakan Sapi Perah (Studi Kasus Pemerahan Susu Sapi Perah Meoria Kudus Jawa Tengah). Semarang: Universitas Diponegoro, 2009.

[15] D. Jong and R. Kemp, "Determinants Of CoWorkers Innovative Behaviour: An Investigation Into Knowlegde Intensive Service," Int. J. Innov. Manag., vol. 7, no. 2, 2003.

[16] N. Firdaus, "Pengentasan Kemiskinan Melalui Pendekatan Kewirausahaan Sosial," Pus. Penelit. Ekon. Lemb. Ilmu Pengetah. Indones., 2014.

[17] G. H. Kusuma and N. Purnamasari, Baseline Research BumDes: Kewirausahaan Sosial Yang Berkelanjutan. Yogyakarta: Penabulu Foundation, 2016.

[18] N. M. Dwi Rina, “Tingkat Kesejahteraan Anggota BumDes Murti Desa Anturan Kecamatan Buleleng Melalui Pendekatan Kewirausahaan Sosial," 2019. 